\title{
Hubungan Sikap dan Motivasi Perawat dalam Pelaksanaan Pendidikan Pasien dan Keluarga terhadap Pencegahan Kekambuhan Pasien Gangguan Jiwa
}

\author{
Dwi Kartika Pebrianti \\ Prodi S1 Keperawatan STIKes Baiturrahim Jambi, Indonesia \\ Email :dwiekartika86@gmail.com
}

Submitted : 05/12/2020

Accepted: 21/01/2021

Published: 06/03/2021

\begin{abstract}
One of the causes of the high recurrence rate in mental illness patients is the lack of understanding of the patient and their family in caring for patients at home after returning from the mental hospital. This understanding is obtained through the educational process provided by health workers, one of which is a nurse. Health education for patients and their families is very necessary for patient independence after returning home, especially for patients with mental disorders. This study aims to determine the relationship between attitudes and motivation of nurses in implementing patient and family education in mental hospitals. This research used quantitative methods with cross sectional approach. The sample size is 117 nurses. The sampling technique used was proportional random sampling technique. Place of research in the inpatient room of the Jambi Province Mental Hospital. The bivariate analysis found that there was a nurse motivation (0.03) with the performance of nurses in providing health education to patients and their families. While the data analysis attitude variable has no relationship (p-value: 0.302). It is hoped that nurses as the spearhead of service at RSJD Jambi Province can improve their role and performance in providing health education which contributes to increasing the health status of patients reducing the risk of recurrence due to a lack of understanding of patients and families in caring for patients while at home.
\end{abstract}

Keywords: attitude, motivation, recurrence

\begin{abstract}
Abstrak
Penyebab tingginya angka kekambuhan pada pasien gangguan jiwa salah satunya adalah karena kurang pahamnya pasien dan keluarga dalam merawat pasien di rumah setelah pulang dari rumah sakit jiwa. Pemahaman tersebut didapat melalui proses pendidikan yang diberikan tenaga kesehatan, salah satunya adalah perawat. Pendidikan kesehatan pada pasien dan keluarga sangat diperlukan untuk kemandirian pasien setelah pulang kerumah, terutama pada pasien dengan gangguan jiwa. Penelitian ini bertujuan untuk mengetahui hubungan sikap dan motivasi perawat pelaksanaan pendidikan pasien dan keluarga di rumah sakit jiwa. Penelitian menggunakan metode kuantitatif dengan pendekatan cross sectional. Jumlah sampel 117 orang perawat. Teknik pengambilan sampel menggunakan propotional random sampling. Tempat penelitian di ruang Rawat Inap RS Jiwa Provinsi Jambi. Hasil diperoleh ada hubungan motivasi perawat $(0,03)$ dengan kinerja perawat dalam pemberian pendidikan kesehatan pada pasien dan keluarga. Sedangkan variabel sikap tidak ada hubungan ( $p$-value : 0,302). Diharapkan bahwa perawat sebagai ujung tombak pelayanan di RSJD Provinsi Jambi dapat meningkatkan peran dan kinerjanya dalam memberikan pendidikan kesehatan yang berkontribusi pada meningkatnya derajat kesehatan pasien mengurangi resiko kekambuhan akibat kurang pemahaman pasien dan keluarga dalam merawat pasien selama di rumah.
\end{abstract}

Kata kunci: kekambuhan, motivasi, sikap 


\section{PENDAHULUAN}

Menurut Gillies (2004) Kinerja perawat dalam memberikan pelayanan keperawatan mempunyai 3 jenis yakni asuhan langsung kepada pasien, asuhan tidak langsung dan penyuluhan kesehatan. Pelaksanaan pendidikan pasien dan keluarga merupakan salah satu bentuk kinerja perawat dalam pelayanan keperawatan. Kinerja perawat dapat ditunjukkan oleh perawat dalam melaksanakan tugas-tugas asuhan keperawatan, seperti memberikan edukasi kepada pasien dan keluarga sehingga menunjukkan hasil yang baik bagi perawat dalam kurun waktu tertentu (Kurniadi, 2013).

Faktor yang mempengaruhi kinerja Menurut Gibson et al (1987, yaitu faktor individu, faktor organisasi dan faktor psikologis. Faktor individu dikelompokkan adalah demografi yaitu karakteristik dari individu berupa umur, tingkat pendidikan, masa kerja, status kepegawaian. Faktor organisasi berupa sumber daya, kepemimpinan, imbalan dan supervisi. Faktor psikologis berupa sikap, persepsi dan motivasi (Ilyas, 2013).

Kemampuan atau kinerja diartikan sebagai suatu tingkat pencapaian individu terhadap upaya untuk menyelesaikan pekerjaannya dengan baik dan efisien, terdapat 2 subvariabel psikologis yang mempengaruhi kinerja yakni sikap dan motivasi. Sikap merupakan sebuah itikat dalam diri seseorang untuk tidak melakukan atau melakukan pekerjaan tersebut sebagai bagian dan aktivitas yang menyenangkan. Motivasi dapat didefenisikan sebagai suatu kondisi yang berpengaruh membangkitkan, mengarahkan dan memelihara perilaku yang berhubungan dengan lingkungan kerja (Mangkunegara, 2009).

Tingginya angka kekambuhan pada pasien yang mengalami gangguan jiwa salah satu faktor penyebabnya disinyalir karena kurang pahamnya klien dan keluarga dalam melakukan perawatan di rumah pasca pengobatan di Rumah Sakit Jiwa. Pemahaman tentang cara perawatan klien gangguan jiwa didapatkan salah satu sumbernya ialah melalui petugas kesehatan yakni perawat. Perawat memberikan informasi dan pendidikan kesehatan tentang perawatan klien selama di rumah dengan menjalankan perannya sebagai educator. Informasi yang diterima oleh klien dan keluarga diharapkan dapat dipahami dan dijalankan sesuai dengan program pengobatan sehingga dapat menekan angka kekambuhan klien gangguan jiwa (Sheewangisaw, 2012).

Perawat sebagai salah satu pemberi pelayanan asuhan kepada pasien mempunyai peran dan fungsi yang penting untuk membantu penanganan permasalahan kesehatan dan keperawatan (Yosef, 2007). Pemberian asuhan keperawatan merupakan proses teraupetik yang melibatkan hubungan kerjasama antara perawat dengan klien, keluarga atau masyarakat untuk mencapai tingkat kesehatan yang optimal. Salah satu bentuk pemberian asuhan keperawatan ialah pemberian edukasi perawat kepada pasien dan keluarga dengan kompetensi yang telah dimiliki (Keliat, 2009).

\section{METODE PENELITIAN}

Penelitian ini dilakukan seluruh tenaga perawat yang berada di rawat Inap 
RSJD Jambi sebanyak 117 orang. Instrument penelitian yang digunakan adalah menggunakan kuesioner. Tujuan penelitian untuk mengetahui hubungan sikap dan motivasi perawat pelaksanaan pendidikan pasien dan keluarga terhadap pencegahan kekambuhan pasien gangguan jiwa. Data dianalisis secara univariat dan bivariat dengan menggunakan uji chi square.

\section{HASIL DAN PEMBAHASAN}

Hasil penelitian ini meliputi analisa univariat yang meliputi sikap dan motivasi, dan di RSJD Provinsi Jambi , kemudian dilanjutkan dengan analisa bivariat. Hasil analisa penelitian yang telah diperoleh dijabarkan, sebagai berikut:

Analisis Univariat

Gambaran Pemberian Pendidikan Pasien dan Keluarga

Tabel 1 Distribusi frekuensi responden berdasarkan Kinerja perawat dalam pemberian pendidikan pasien dan keluarga $(n=117)$

\begin{tabular}{llcc}
\hline Independen & Kategori & $\mathbf{N}$ & $\mathbf{\%}$ \\
\hline & $\begin{array}{l}\text { Kurang } \\
\text { baik }\end{array}$ & 20 & 17,1 \\
& Baik & 97 & 82,9 \\
\hline
\end{tabular}

Berdasarkan tabel 1 menunjukkan bahwa sebagian besar kinerja perawat dalam pemberian pendidikan pasien dan keluarga dinyatakan baik yaitu $82,9 \%$.

Gambaran Sikap dan Motivasi Perawat di Ruang Rawat Inap

Tabel 2 Distribusi frekuensi responden berdasarkan sikap dan motivasi perawat di Ruang rawat inap $(n=117)$

\begin{tabular}{ccccc}
\hline No & $\begin{array}{c}\text { Variabel } \\
\text { Dependen }\end{array}$ & Kategori & N & $\%$ \\
\hline 1 & Sikap & Negatif & 55 & 47,0 \\
& & Positif & 62 & 53,0 \\
2 & Motivasi & Rendah & 48 & 41,0 \\
& & Tinggi & 69 & 59,0 \\
\hline
\end{tabular}

Berdasarkan tabel 2 menunjukkan bahwa sebagian besar responden berpendidikan, lebih dari sebagian responden mempunyai sikap yang positif yaitu sebanyak $62(53,0 \%)$ responden dan lebih dari sebagai responden yang mempunyai motivasi tinggi yaitu sebanyak $69(59,0 \%)$ responden

Hasil penelitian ini menunjukkan bahwa sikap perawat pelaksana akan menentukan kecenderungan perilaku yang ada didalam diri seorang perawat, hal ini berkaitan dengan objek sikap yang dihadapinya dan disadari kepercayaan dan perasaannya. Apabila perawat percaya bahwa pelaksanaan pendidikan pasien dan keluarga adalah hal yang penting dan berdampak pada kualitas pelayanan yang diberikan kepada masyarakat dan itu adalah tanggung jawabnya maka perawat akan melibatkan diri ikut dalam melaksanakan pendidikan pasien dan keluarga tersebut sehingga menghasilkan kinerja yang baik.

Hasil analisis univariat variabel motivasi didapatkan motivasi perawat dalam pelaksanaan pendidikan pasien dan keluarga sebagian besar responden mempunyai motivasi yang tinggi yaitu 59,0\%. Sesuai dengan penelitian Polapa (2014) menyatakan bahwa motivasi perawat dalam pelaksanaan dokumentasi asuhan keperawatan sebagian besar baik yaitu $79,4 \%$. Motivasi merupakan suatu proses dimana kebutuhan-kebutuhan mendorong seseorang untuk melakukan serangkian 
kegiatan yang mengarah ke tercapainya suatu tujuan tertentu (Mangkunegara, 2009). Salah satu bentuk motivasi yang sangat berpengaruh terhadap pencapaian hasil yang optimal adalah motivasi yang berasal dari diri sendiri yang mendorong dirinya menjadi produktif (Hasibuan, 2011). Motivasi dapat juga didefinisikan sebagai kesiapan khusus seseorang untuk melakukan atau melanjutkan serangkaian aktivitas yang ditujukan untuk mencapai beberapa sasaran yang telah ditetapkan (Nursalam, 2012). Perawat memiliki tingkat motivasi yang rendah. Mereka tidak termotivasi sebagai akibat ketidakpuasan dengan remunerasi; Kesempatan untuk pertumbuhan dan promosi; kondisi kerja; Pengakuan, penghargaan dan penghargaan; Serta tunjangan dan tunjangan (Onuoha, 2016).

\section{Analisa Bivariat}

Hubungan sikap dan motivasi perawat dengan pemberian pendidikan pasien dan keluarga

Tabel 3 Hubungan sikap dan motivasi dengan Pemberian pendidikan pasien dan keluarga $(n=117)$

\begin{tabular}{|c|c|c|c|}
\hline \multirow{3}{*}{$\begin{array}{c}\text { Variabel } \\
\text { Independ } \\
\text { en }\end{array}$} & \multicolumn{3}{|c|}{$\begin{array}{l}\text { Pelaksanaan pendidikan } \\
\text { pasien dan keluarga }\end{array}$} \\
\hline & $\begin{array}{c}\text { Kurang } \\
\text { Baik }\end{array}$ & Baik & Total \\
\hline & $\%$ & $\%$ & $\mathbf{N}$ \\
\hline
\end{tabular}

\begin{tabular}{lccccccc}
\hline \multicolumn{1}{c}{ Sikap } & & & & & & & \\
Negatif & 12 & 21, & 4 & 78, & 5 & 10 & \\
& & 8 & 3 & 2 & 5 & 0 & 0,30 \\
Positif & 8 & 12, & 5 & 87, & 6 & 10 & 2 \\
& & 9 & 4 & 1 & 2 & 0 & \\
\hline Motivasi & & & & & & & \\
Rendah & 13 & 27, & 3 & 72, & 4 & 10 & 0,03 \\
& & 1 & 5 & 9 & 8 & 0 & 2 \\
Tinggi & 7 & 10, & 6 & 89, & 6 & 10 & \\
& & 1 & 2 & 9 & 9 & 0 & \\
\hline
\end{tabular}

Berdasarkan tabel 3 diatas menunjukkan dari 55 responden yang mempunyai sikap negatif pemberian pendidikan pasien dan keluarga kurang baik $21,8 \%$ dan baik $78,2 \%$. Sedangkan dari 62 responden yang mempunyai sikap positif dengan pemberian pendidikan pasien dan keluarga kurang baik 12,9\% dan baik $87,1 \%$. Hal ini menunjukkan bahwa sikap perawat yang positif lebih besar memiliki pemberian pendidikan pasien dan keluarga yang baik. Hasil uji statistik didapatkan bahwa $p$ value $(0,302)>0,05$ yang berarti tidak ada hubungan yang signifikan antara sikap dengan pemberian pendidikan pasien dan keluarga. Dari 48 responden yang motivasi rendah dengan pemberian pendidikan pasien dan keluarga kurang baik $27,1 \%$ dan baik $72,9 \%$. Sedangkan dari 69 responden yang motivasi tinggi dengan pemberian pendidikan pasien dan keluarga kurang baik $10,1 \%$ dan baik $89,9 \%$. Hal ini menunjukkan bahwa perawat dengan motivasi yang tinggi memiliki sebagian besar pemberian pendidikan pasien dan keluarga yang baik. Hasil uji statistik didapatkan bahwa bahwa $p$ value $(0,032)<$ 0,05 yang berarti ada hubungan yang signifikan antara motivasi dengan pemberian pendidikan pasien dan keluarga Penelitian ini tidak sesuai dengan penelitian Suarni (2013) yang menemukan bahwa pada variabel sikap menunjukkan bahwa perawat di ruang bedah yang memiliki sikap positif cenderung memiliki kinerja yang baik pula dalam pendokumentasian asuhan keperawatan sebanyak 24 orang $(82,8 \%)$. Sedangkan perawat yang memiliki sikap negatif cenderung memiliki kinerja yang kurang sebanyak 12 orang $(54,5 \%)$ lebih tinggi 
dibandingkan dengan memiliki kinerja yang baik yaitu sebanyak 10 orang $(45,5 \%)$.

Jeffrey (2011) mendefinisikan sikap sebagai mental atau saraf keadaan kesiapan, terorganisir melalui pengalaman, mengerahkan sebuah perintah atau pengaruh dinamis terhadap respon individu terhadap semua objek dan situasi yang terkait dengannya. Definisi sikap yang lebih sederhana adalah pola pikir atau kecenderungan untuk bertindak dengan cara tertentu karena individu pengalaman dan temperamen.

Hasil analisa bivariat antara motivasi dengan pelaksanaan pendidikan pasien dan keluarga menunjukkan bahwa responden yang memiliki motivasi rendah dengan pelaksanaan pendidikan pasien dan keluarga yang kurang baik $27,9 \%$ dan $72,1 \%$ baik. Sedangkan responden yang memiliki motivasi tinggi dengan kinerja pelaksanaan pendidikan pasien dan keluarga kurang baik hanya $10,1 \%$ dan $89,9 \%$ baik. Hasil uji statistik didapatkan bahwa ada hubungan yang signifikan antara motivasi dengan pelaksanaan pendidikan pasien dan keluarga ( $p$-value $=0,032$ ).

Hasil penelitian ini sejalan dengan penelitian Yanti \& Warsito (2013) yang menyatakan bahwa ada hubungan motivasi dengan kualitas dokumentasi asuhan keperawatan ( $p$ value $=0,036$ ). Juga sejalan dengan Mudayana (2010) bahwa motivasi kerja yang semakin tinggi menjadikan perawat mempunyai semangat yang tinggi untuk memberikan pelayanan yang terbaik sebanding dengan motivasi untuk melakukan pendokumentasian yang tinggi akan menghasilkan kualitas dokumentasi yang baik.

Penelitian yang dilakukan Onuoha (2016) mendapatkan bahwa Perawat di
Trinidad dan Tobago memiliki tingkat motivasi yang rendah. Mereka tidak termotivasi sebagai akibat ketidakpuasan dengan remunerasi; Kesempatan untuk pertumbuhan dan promosi; kondisi kerja; Pengakuan, penghargaan dan penghargaan; Serta tunjangan (Onuoha, 2016). Penelitian Gomes F \& Froenca T (2015) menyatakan bahwa banyak bukti yang dapat menggambarkan bagaimana kinerja dan motivasi saling berhubungan. Ada penelitian yang menunjukkan peningkatan kinerja pada pekerja dengan kompensasi yang memuaskan.

Motivasi merupakan suatu proses dimana kebutuhan-kebutuhan mendorong seseorang untuk melakukan serangkaian kegiatan yang mengarah ke tercapainya suatu tujuan tertentu (Mangkunegara, 2009). Hasibuan (2011) menyatakan motivasi sebagai kekuatan yang mendorong seorang karyawan dalam menimbulkan dan mengarahkan perilaku. Motivasi dapat juga didefinisikan sebagai kesiapan khusus seseorang untuk melakukan atau melanjutkan serangkaian aktivitas yang ditujukan untuk mencapai beberapa sasaran yang telah ditetapkan (Nursalam, 2012).

\section{SIMPULAN}

Kesimpulan dari penelitian ini adalah bahwa pemberian pendidikan pasien dan keluarga pencegehan kekambuhan pasien diyang dilakukan oleh perawat sebagian besar sudah dijalankan dengan baik, mempunyai sikap yang positif dan mempunyai motivasi yang tinggi dalam memberikan pendidikan pasien dan keluarga. Dari variabel independen yang dinilai variabel motivasi mempunyai hubungan yang bermakna dengan kinerja perawat dalam pemberian pendidikan pasien dan keluarga ( $p$ value < 0,05). Sedangkan variabel sikap secara analisa 
statistic tidak mempunyai hubungan yang signifikan dengan kinerja perawat dalam pemberian pendidikan pasien dan keluarga ( $p$ value $>0,05$ ).

\section{SARAN}

Diharapkan perawat sebagai ujung tombak pelayanan dapat terus meningkatkan peran dan tugasnya dalam pemberian pendidikan pasien dan keluarga yang dapat berkontribusi pada meningkatkan derajat kesehatan masyarakat dan mengurangi resiko kekambuhan akibat kurang pemahaman pasien dan keluarga dalam merawat pasien selama di rumah.

\section{DAFTAR PUSTAKA}

Alizera, et al. 2013. Knowledge and Performance about Nursing Ethic Codes from Nurses' and Patients' Perspective in Tabriz Teaching Hospitals, Iran. http:// journals.tbzmed.ac.ir/ JCS

Gillies, D.A.2004. Manajemen Keperawatan: suatu pendekatan sistem. Edisi ketiga. Philadelphia : W.B saunders Company. Gomes, F., \& Proenca, T. (2015). Nurses' Motivation and Satisfaction at Work: An Exploratory Study at the Centro Hospitalar S. Joao (1st Ed.); FEP ECONOMICS AND MANAGEMENT. Retrieved from https://www.google.tt/?gfe_rd=cr\&ei= rl8YVqqfGKmm8wfFvbjADw\&gws $\underline{\mathrm{rd}=\mathrm{ssl} \# \mathrm{q}=\text { Nurses } \% 27+\text { Motivation }+\mathrm{an}}$
d+Satisfaction+at+Work+ISSN:+087 0-8541.

Hasibuan, Malayu, S.P.2011 Manajemen Sumber Daya Manusia. Edisi Revisi. Jakarta.

Ilyas, Y. 2013. Perencanaan SDM Rumah Sakit: Teori, Metoda, dan Formula. (cetakan pertama). Jakarta Keliat, A. 2009. Model Praktik Keperawatan Profesional Jiwa. Jakarta : EGC

Kurniadi A. 2013. Manajemen Keperawatan dan Prospektifnya. Edisi ke 1 FKUI, Jakarta. 122 - 27

Mangkunegara. 2009. Evaluasi Kinerja Sumber Daya Manusia, Cetakan Pertama. PT.Refikaditama, Bandung.

Nursalam.2012. Manajemen Keperawatan Aplikasi dan Praktek. Jakarta : Salemba medika. Onuoha, P., et al.2016. Motivational factors and techniques at the workplace: perspectives of nurses in two major hospitals in Trinidad. Asian Journal of Science and Technology,

Potter PA, Perry AG, Astle B, Duggleby W (2014). Canadian Fundamentals of Nursing. ( $5^{\text {th }}$ ed.). Mosby: Toronto. ISBN: 978-1-926648-53-8. Saleem. A. Ghafar. A.Ibrahim. M. Yousuf, M dan Ahmed. N. 2015. Product Perceived qualityband prlueschase intention with consumer satisfaction. Global Journal of Management and Busines Research: E-Marketing

Robbins S.P. 2015. Organizational behavior. San Diago State University : Prentice Hall.

Yosep, 2007. Keperawatan Jiwa. Bandung Refika Aditama. 